\title{
Cyclic tensile strain affects the response of human periodontal ligament stromal cells to tumor necrosis factor-a
}

\author{
Zhongqi Zhao $^{1} \cdot$ Christian Behm $^{1,2} \cdot$ Marco Aoqi Rausch $^{1,2} \cdot$ Zhiwei Tian $^{1} \cdot$ Xiaohui Rausch-Fan $^{3} \cdot$ Oleh Andrukhov $^{1}$ (I)
}

Received: 5 March 2021 / Accepted: 14 June 2021 / Published online: 29 June 2021

(c) The Author(s) 2021

\begin{abstract}
Objectives Orthodontic treatment in adult patients predisposed to mild or severe periodontal disease is challenging for orthodontists. Orthodontic malpractice or hyper-occlusal forces may aggravate periodontitis-induced destruction of periodontal tissues, but the specific mechanism remains unknown. In the present study, the combined effect of mechanical stress and tumor necrosis factor (TNF)- $\alpha$ on the inflammatory response in human periodontal ligament stromal cells (hPDLSCs) was investigated.

Materials and methods hPDLSCs from 5 healthy donors were treated with TNF- $\alpha$ and/or subjected to cyclic tensile strain (CTS) of $6 \%$ or $12 \%$ elongation with $0.1 \mathrm{~Hz}$ for 6 - and $24 \mathrm{~h}$. The gene expression of interleukin (IL)-6, IL-8 and cell adhesion molecules VCAM and ICAM was analyzed by qPCR. The protein levels of IL-6 and IL-8 in conditioned media was measured by ELISA. The surface expression of VCAM- 1 and ICAM-1 was quantified by immunostaining followed by flow cytometry analysis.

Results TNF- $\alpha$-induced IL- 6 gene and protein expression was inhibited by CTS, whereas TNF- $\alpha$-induced IL- 8 expression was decreased at mRNA expression level but enhanced at the protein level in a magnitude-dependent manner. CTS downregulated the gene expression of VCAM- 1 and ICAM- 1 under TNF- $\alpha$ stimulation, but the downregulation of the surface expression analyzed by flow cytometry was observed chiefly for VCAM-1.

Conclusions Our findings show that mechanical force differentially regulates TNF- $\alpha$-induced expression of inflammatory mediators and adhesion molecules at the early stage of force application. The effect of cyclic tensile strain is complex and could be either anti-inflammatory or pro-inflammatory depending on the type of pro-inflammatory mediators and force magnitude.

Clinical relevance Orthodontic forces regulate the inflammatory mediators of periodontitis. The underlying mechanism may have significant implications for future strategies of combined periodontal and orthodontic treatment.
\end{abstract}

Keywords Human periodontal ligament stromal cells · Orthodontic force $\cdot$ Mechanical loading $\cdot$ Periodontitis ·

Inflammatory cytokine

\section{Introduction}

Oleh Andrukhov

oleh.andrukhov@meduniwien.ac.at

1 Competence Center for Periodontal Research, University Clinic of Dentistry and Periodontology, Medical University of Vienna, Sensengasse 2A, 1090 Vienna, Austria

2 Division of Orthodontics, University Clinic of Dentistry, Medical University of Vienna, 1090 Vienna, Austria

3 Center for Clinical Research, University Clinic of Dentistry, Medical University of Vienna, 1090 Vienna, Austria
Periodontal ligament (PDL) is a connective tissue between the cementum and the alveolar bone, which supports the teeth and is continuously subjected to and responding to varied types of biomechanical forces [1, 2]. During orthodontic treatment, appropriate mechanical force squeezes or stretches the PDL, regulating a coordinated remodeling process which consists of bone resorption at compression side and bone formation at tension side of the alveolar bone, and culminating in the orthodontic tooth movement (OTM) [3]. This process highly depends on the cellular components of PDL, which principally consist of undifferentiated 
resident mesenchymal stromal cells (MSCs), fibroblasts and osteoblasts [1]. Human periodontal ligament stromal cells (hPDLSCs), the resident MSCs, are a heterogeneous cell population and have a fibroblast-like morphology $[4,5]$. They are multipotent progenitor cells expressing specific MSC surface markers, displaying multi-lineage differentiation potential $[5,6]$ and exerting immunomodulatory effects [7]. hPDLSCs are reported to be sensitive to mechanical loading and play a central role in bone remodeling during OTM [8].

Currently, an increasing number of adult patients predisposed to mild or severe periodontal disease are seeking orthodontic treatment, leading to the challenges of maintaining homeostasis of the periodontium which orthodontists have to face [9]. It is known that orthodontic malpractice or hyper-occlusal forces may aggravate periodontitis-induced destruction of periodontal tissues [10]. The periodontal tissue of periodontitis patients is considered to be more sensitive and less tolerant to mechanical loading than that in healthy individuals [11-14] but the underlying mechanisms for the co-destructive effect are not yet clear. Tumor necrosis factor- $\alpha$ (TNF- $\alpha)$ is a primary and initial inflammatory cytokine which is highly correlated with the pathogenesis of periodontitis $[15,16]$. TNF- $\alpha$ up-regulates the expression of numerous inflammatory mediators in hPDLSCs, particularly IL-6, IL-8, vascular cell adhesion molecule 1 (VCAM-1), and intercellular adhesion molecule 1 (ICAM-1) [16-18]. IL-6 is closely related to bone destruction through its effects on osteoclastogenesis $[19,20]$; IL-8 plays a key role in the recruitment and activation of neutrophils to the site of tissue damage or infection [21]. VCAM-1 and ICAM-1 stimulate leukocyte recruitment required for inflammation [18]. Furthermore, ICAM-1 and VCAM-1 mediate the immunomodulatory function of MSCs [22].

Orthodontic treatment also stimulates various inflammatory mediators in response to mechanical forces. During orthodontic tooth movement, the ongoing remodeling process begins with an initial aseptic inflammatory response [23]. This is characterized by production of numerous mediators like IL-1 $\beta$, IL-6, IL-8, and TNF- $\alpha$ [11, 24-27], which are also involved in the progression of periodontitis. Therefore, interference between the biological mediators induced by mechanical stimulation and periodontal inflammation might contribute to the co-destructive effect, which is not always confirmed by experimental data. Qualitatively, the impact of orthodontic forces on the inflammatory response seems to depend on force magnitude $[9,28]$. On the one hand, in vitro studies on human PDL cells reported that mechanical forces with the magnitude of $12-20 \%$ aggravated inflammatory response induced by bacterial components $[29,30]$. Furthermore, an in vivo study reported that orthodontic force up-regulated the expression of IL- $1 \beta$ and TNF- $\alpha$ in periodontitis rats and amplified bone loss [11].
On the other hand, a number of studies have shown that low magnitude-mechanical forces with magnitude up to $10 \%$ can also exert anti-inflammatory effects in human PDL cells [28, 31, 32].

Hence, the impact of mechanical load to the inflammatory response should be still investigated. Of particular interest is the question how the mechanical load might influence the response of hPDLSCs to the inflammatory environment. Although TNF- $\alpha$ is involved in both periodontitis and orthodontic tooth movement, the combined effect of TNF- $\alpha$ and mechanical strain on the inflammatory responses was never investigated in hPDLSCs to date. Therefore, the aim of the present in vitro study was to investigate the effects of CTS of different magnitudes on TNF- $\alpha$-induced inflammatory response in hPDLSCs. CTS with either $6 \%$ or $12 \%$ elongation was applied to identify the role of low and high magnitude orthodontic forces. Cells were stimulated for either 6 or $24 \mathrm{~h}$, because these time points reflect the initial stage of applied mechanical forces during orthodontic treatment [33], at which the inflammatory processes play the most essential role [34]. The TNF- $\alpha$-induced response was evaluated based on the resulting expression of IL-6, IL-8, VCAM-1, and ICAM-1.

\section{Materials and methods}

\section{Cell culture}

All the procedures were performed in accordance with the Declaration of Helsinki and the "Good Scientific Practice" guidelines of the Medical University of Vienna and approved by the Ethics Committee of the Medical University of Vienna (ethical approval number: 1079/2019, extended in 2019). Primary hPDLSCs of 5 periodontally healthy patients were isolated from the third molars extracted for orthodontic reasons. Periodontal ligaments were dissected from the middle third of the root surface and cultured in Dulbecco's modified Eagles Medium (DMEM, Sigma-Aldrich, St. Louis, USA), supplemented with $10 \%$ fetal bovine serum (FBS, Gibco, Carlsbad, USA), $100 \mathrm{U} / \mathrm{ml}$ penicillin and $50 \mu \mathrm{g} / \mathrm{ml}$ streptomycin (P/S, Gibco, Carlsbad, CA, USA). Outgrowing cells were kept at $37^{\circ} \mathrm{C}$ under an atmosphere of $95 \%$ humidity and $5 \% \mathrm{CO}_{2}$. After reaching confluency, cells were detached with accutase (Sigma-Aldrich, St. Louis, USA) and passaged. Cells between passage 4-7 were used in all subsequent experiments. The phenotype of isolated hPDLSCs was verified according to our recent study [4]: cells were positively stained with mesenchymal cell markers (CD29, CD73, CD90, CD105, and CD146) and negatively stained with hematopoietic stem cell markers (CD31, CD34, and CD45), which is in agreement with the official criteria for MSCs from the International Society for Cell and Gene 
Therapy (ISCT) [35, 36]. The representative FACS dot plots are provided in Supplementary Fig. 1.

\section{Application of tensile strain and TNF- $a$ treatment}

hPDLSCs were seeded onto collagen type I-coated BioFlex ${ }^{\circledR}$ six-well culture plates (Flexcell $®$ International Corporation, Burlington, NC, USA) at the initial density of $1 \times 10^{5}$ cells/ well in $3 \mathrm{ml}$ of DMEM with all supplements. BioFlex ${ }^{\circledR}$ Cell Seeders (Flexcell@ International Corporation, Burlington, $\mathrm{NC}$, USA) were used during plating to confine cells to the central region of the flexible membrane. After one-day incubation in supplemented DMEM cells reached $80-95 \%$ confluence and were serum-starved for $24 \mathrm{~h}$ before the further treatment. The confluent cells were used for the experiments, undergoing inflammatory and/or mechanical stimulation. To mimic a pro-inflammatory microenvironment, hPDLSCs were treated with $10 \mathrm{ng} / \mathrm{ml}$ TNF- $\alpha$ (Invivogen, San Diego, USA) for 6- or $24 \mathrm{~h}$. To simulate mechanical forces at tension sites, hPDLSCs were subjected to a cyclic tensile strain (CTS, 6 or $12 \%$ elongation, sinusoidal curve, $0.1 \mathrm{~Hz}, 6$ or 24 h) using a Flexcell ${ }^{\circledR}$ FX-5000 ${ }^{\mathrm{TM}}$ Tension System (Flexcell@ International Corporation, Burlington, NC, USA). The plates were placed on a loading station on which the vacuum stretched the flexible silicon membrane, causing deformation along the loading post-surface and thereby generating the dynamic equibiaxial tensile strain to attached cells (Fig. 1). The parameters of stretching were chosen to be within the physiological range based on the existing literature [28, 37-40]. Untreated cells were maintained under the same conditions but without mechanical stimulation.

\section{Reverse transcription-quantitative polymerase chain reaction (RT-qPCR)}

After 6- and $24 \mathrm{~h}$ of incubation, hPDLSCs were lysed and mRNA was transcribed into cDNA using TaqMan Gene expression Cells-to-CT kit (Applied Biosystems, Foster
City, USA) following the manufacturer's instruction. Reverse transcription was performed using Primus 96 advanced thermocycler (Peq/Lab/VWR, Darmstadt, Germany) with the following settings: $37^{\circ} \mathrm{C}$ for $1 \mathrm{~h}$ and $95^{\circ} \mathrm{C}$ for $5 \mathrm{~min}$ followed by $4{ }^{\circ} \mathrm{C}$. Quantitative analysis of the gene expression was done using a QuantStudio 3 device (Applied Biosystems, Foster City, USA). The following TaqMan Gene Expression Assays (Applied Biosystems, Foster City, USA) were used with following ID numbers: IL-6, Hs00985639_m1; IL-8, Hs00174103_m1; VCAM1, Hs00365486_m1; ICAM-1, Hs00164932_m1; and glyceraldehyde-3-phosphate dehydrogenase (GAPDH), Hs99999905_m1. The reaction was performed by heated at $95{ }^{\circ} \mathrm{C}$ for $10 \mathrm{~min}$ and then followed by 50 cycles, each cycle consisting of denaturation at $95{ }^{\circ} \mathrm{C}$ for $15 \mathrm{~s}$ and annealing/extension at $60{ }^{\circ} \mathrm{C}$ for $1 \mathrm{~min}$. The expression of target genes was calculated using $2^{-\Delta \Delta \mathrm{Ct}}$ method, using GAPDH as the housekeeping gene and untreated cells as a control [41].

\section{Enzyme-linked immunosorbent assay}

After 6- and $24 \mathrm{~h}$ of incubation, conditioned media were harvested and protein levels of IL- 6 and IL- 8 were measured using Human Uncoated IL-6 ELISA and Human Uncoated IL-8 ELISA (both from ThermoFisher Scientific, Waltham, USA) according to the manufacturer's instruction. The optical density (OD) was measured at $450 \mathrm{~nm}$ and $570 \mathrm{~nm}$ using a Synergy HTX multi-mode reader (BioTek Instruments, Winooski, USA). After subtracting $\mathrm{OD}_{570}$ from $\mathrm{OD}_{450}$, final concentrations were calculated by plotting determined OD values against the appropriate standard curve using Gen5 All-In-One Microplate Reader Software version 2.09 (BioTek Instruments, Winooski, USA). The detection limit was $2 \mathrm{pg} / \mathrm{ml}$ for both IL-6 and IL-8. All values below the detection limit were considered as zero for the analysis.
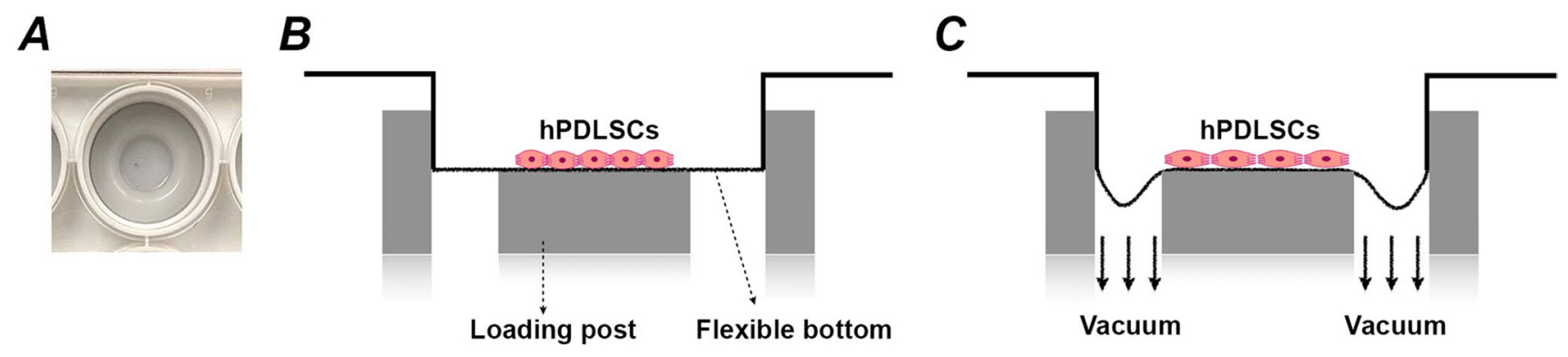

Fig. 1 Schematic of mechanical force loading. (a) BioFlex® Cell Seeders were applied before seeding to confine the cell suspension in the central area of a well in the culture plates. (b) The culture plates were transferred onto the loading post after seeding hPDLSCs at a density of $1 \times 10^{5}$ cells/well in the central region of the flexible membrane using BioFlex ${ }^{\circledR}$ Cell Seeders. (c) Cells were stretched by a cyclic tensile strain (equibiaxial, 6 or $12 \%$ elongation, sinusoidal curve, $0.1 \mathrm{~Hz}, 6$ or $24 \mathrm{~h}$ ) when the vacuum was applied 


\section{Flow cytometry}

After 6- and $24 \mathrm{~h}$ of incubation, the surface expression of VCAM-1 and ICAM-1 was measured by flow cytometry similarly to previously described methods [42]. Briefly, cells were harvested, resuspended in FACS buffer (PBS supplemented with $3 \%$ BSA and $0.09 \%$ of $\mathrm{NaN}_{3}$ ) and fixed with $2 \%$ (v/v) formaldehyde (Merck KGaA, Darmstadt, Germany) for $30 \mathrm{~min}$ at room temperature. After washing and resuspending hPDLSCs in FACS buffer, the cells were stained 1:50 with phycoerythrin (PE)-conjugated mouse anti-human CD106 (VCAM-1) antibody or CD54 (ICAM-1) antibody (both from eBioscience, San Diego, USA) for $30 \mathrm{~min}$ in the dark at room temperature. Following washing singlecell suspensions were prepared in $400 \mu \mathrm{l}$ FACS buffer. Surface marker expression was analyzed using the Attune NxT Acoustic Focusing Cytometer (ThermoFisher Scientific, Waltham, USA). Unstained hPDLSCs were used as control to define the positive threshold and adjust the instrument settings. The percentage of VCAM-1 or ICAM-1 positive hPDLSCs and the corresponding mean fluorescence intensities (MFI) were determined using Attune NxT software version 3.1.2 (ThermoFisher Scientific, Waltham, USA). In total, 10.000 cells were acquired per sample.

\section{Statistical analysis}

All measured data were analyzed using SPSS 20.0 software (IBM, Armonk, USA). Normal distribution was proved by Kolmogorov-Smirnov test. Differences between groups were assessed by Wilcoxon signed-rank test, and pairedsamples Student's t-test. $p$ values $<0.05$ were considered significant. Data are presented as mean \pm standard deviation of at least 5 independent repetitions with hPDLSCs isolated from at least 5 different individuals. Each experiment was performed with technical duplicates.

\section{Results}

\section{Effects of TNF- $\alpha$ on IL- 6 and IL-8 gene and protein expression}

Figure 2 shows the effect of TNF- $\alpha$ on IL- 6 and IL- 8 expression in hPDLSCs. Exposure of hPDLSCs to TNF- $\alpha$ enhanced gene expression of IL-6 and IL-8 after both 6and $24 \mathrm{~h}$ (Figs. $2 \mathrm{a}$ and $2 \mathrm{~b}$ ). TNF- $\alpha$-induced gene expression of IL-6 and IL-8 was significantly increased with time. In the absence of TNF- $\alpha$, IL- 6 and IL- 8 were below ELISA's detection limit. After $6 \mathrm{~h}$ incubation in the presence of TNF$\alpha$, IL- 6 was below detection limit in some samples. TNF- $\alpha$ induced the protein production of both IL- 6 and IL-8, which was significantly increased in a time-dependent manner (Figs. 2c and 2d).

\section{Effects of CTS on IL- 6 expression in the absence and presence of TNF-a}

The effect of CTS on basal and TNF- $\alpha$ induced IL- 6 expression in hPDLSCs is shown in Fig. 3. Application of CTS in
A

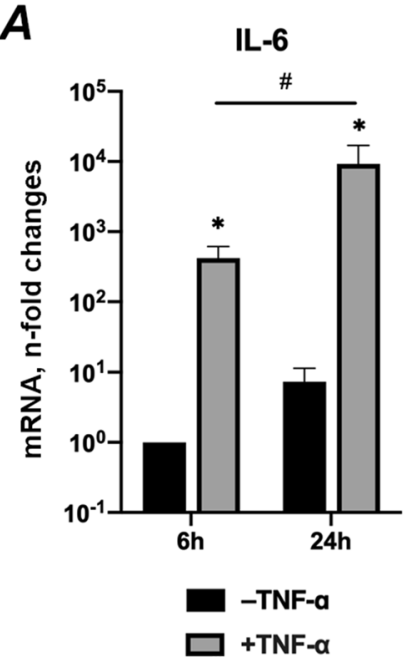

B

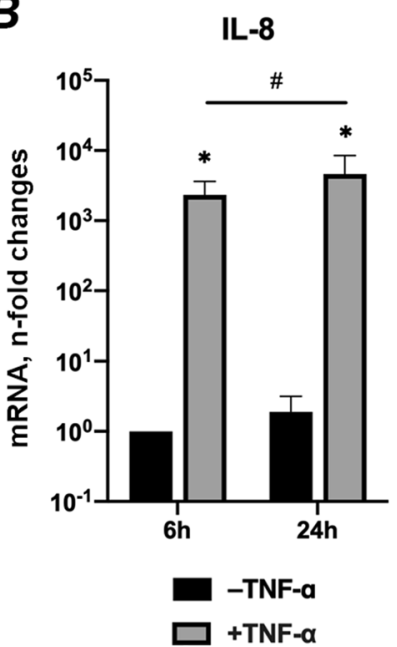

Fig. 2 Effects of TNF- $\alpha$ on gene and protein expression of IL- 6 and IL-8 on unstretched hPDLSCs. Primary hPDLSCs were treated with $10 \mathrm{ng} / \mathrm{ml} \mathrm{TNF}-\alpha$ without mechanical stretching. After 6- or $24 \mathrm{~h}$ of incubation, gene expression levels of IL-6 (a), IL-8 (b) were measured using RT-qPCR. The Y-axes show the $n$-fold changes in mRNA expression compared to untreated control after $6 \mathrm{~h}$ (n-fold expres-

C

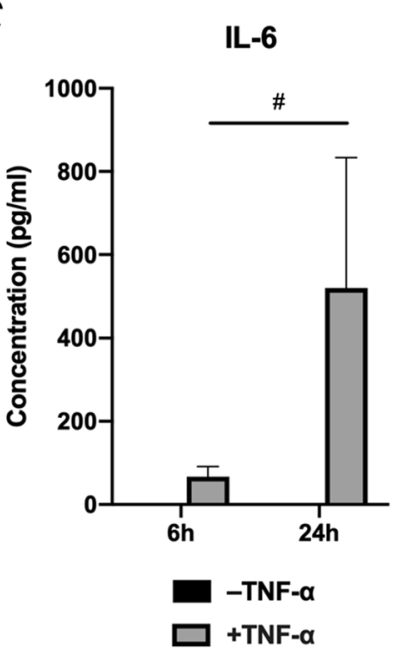

$D$

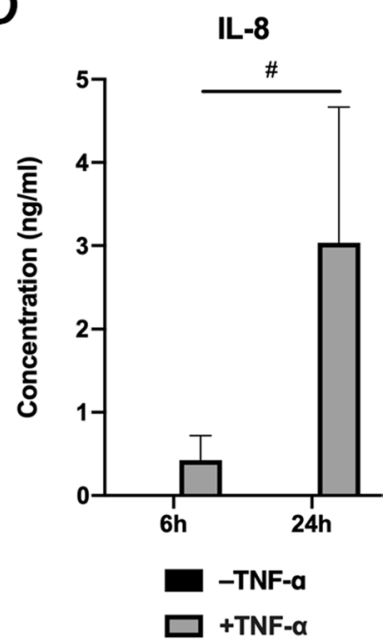

sion =1). The corresponding protein levels of IL-6 (c) and IL-8 (d) in conditioned media were quantified by ELISA. The groups in the absence or presence of TNF- $\alpha$ are indicated as -TNF- $\alpha$ or + TNF- $\alpha$, respectively. The data are presented as the mean \pm standard deviation. $* p<0.05$ compared to corresponding control. ${ }^{\#} p<0.01$ compared between groups as indicated 
Fig. 3 Effects of CTS on IL-6 expression in the absence / presence of TNF- $\alpha$ in hPDLSCs. Primary hPDLSCs were subjected to either $6 \%$ or $12 \%$ cyclic stretching, in the absence or presence of $10 \mathrm{ng} /$ $\mathrm{ml} \mathrm{TNF-} \alpha$ for 6 or $24 \mathrm{~h}$. IL- 6 gene expression levels were measured with RT-qPCR after 6 (a) or 24 (b) hours. TNF$\alpha$-induced IL-6 protein levels after $24 \mathrm{~h} \mathrm{(c)} \mathrm{were} \mathrm{quantified}$ by ELISA. Y-axes show the effect of CTS on IL-6 expression as $\%$ of the values observed in unstretched cells with or without TNF- $\alpha$. For RT-qPCR (a, b), n-fold gene expression was calculated first using the $2^{-\Delta \Delta \mathrm{Ct}}$ method and then the data were normalized to those observed in unstretched cells (100\%, dashed line). For ELISA (c), the values were calculated as $\%$ of the values measured in unstretched cells $(100 \%$, dashed line). The data are presented as the mean \pm standard deviation. * and $* *$ — significantly different compared to unstretched control with $p<0.05$ and $p<0.01$,

respectively
A

IL-6, $6 \mathrm{~h}$

B

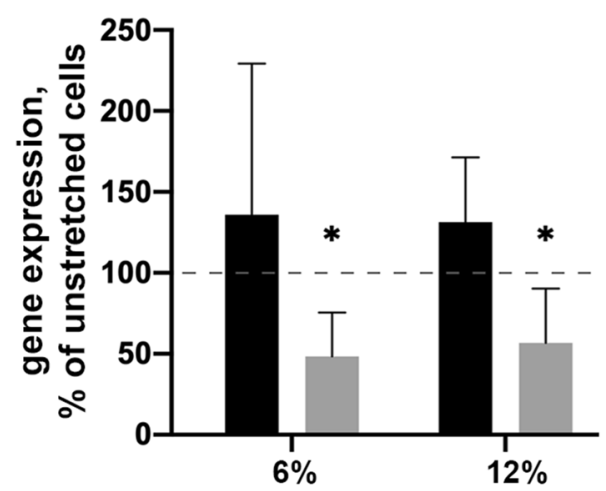

C

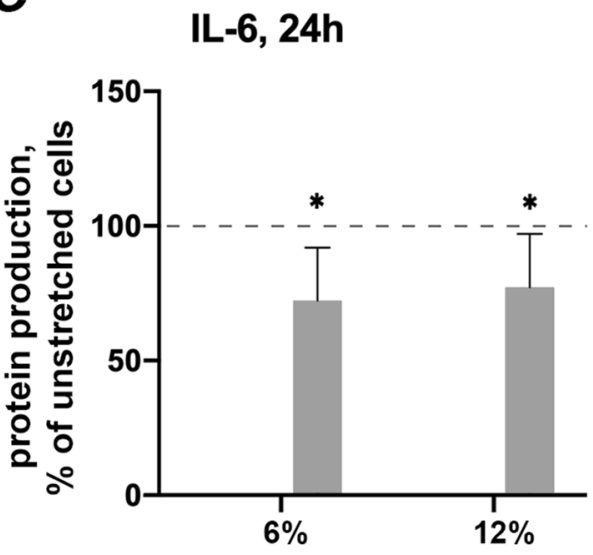

IL-6, 24h

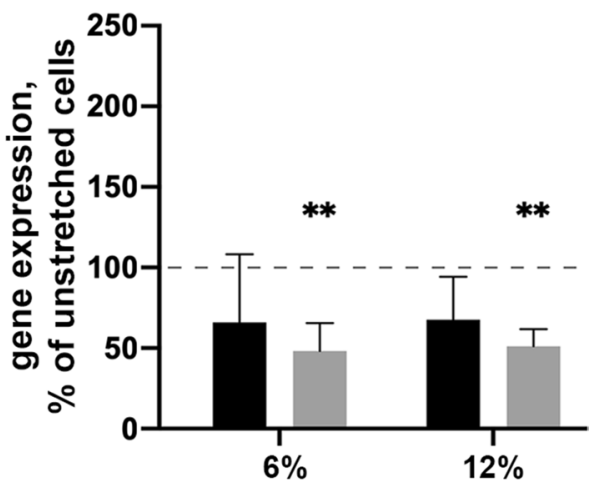

the absence of TNF- $\alpha$ had no significant effect on the gene expression of IL- 6 in hPDLSCs compared to the unstretched control groups (Fig. $3 \mathrm{a}$ and $3 \mathrm{~b}$ ). In contrast, TNF- $\alpha$-induced IL-6 expression was inhibited by CTS at both magnitudes. A significant effect of CTS on TNF- $\alpha$-induced IL- 6 gene expression was observed after both 6- and $24 \mathrm{~h}$ (Figs. 3a and $3 \mathrm{~b}$, respectively). After $24 \mathrm{~h}$, TNF- $\alpha$-induced IL- 6 protein production was significantly decreased by CTS with both $6 \%$ and $12 \%$ elongation (Fig. 3c). The relative IL-6 protein levels were not calculated for $6 \mathrm{~h}$ stimulation, because TNF$\alpha$-induced IL- 6 protein production was below the detection limit in some samples independently on the mechanical stimulation.

\section{Effects of CTS on IL-8 expression in the absence and presence of TNF-a}

Figure 4 shows the effect of CTS on basal and TNF- $\alpha$ induced IL-8 expression in hPDLSCs. CTS applied on hPDLSCs did not influence the IL-8 gene expression level in the absence of TNF- $\alpha$ after both $6-$ and $24 \mathrm{~h}$ (Figs. $4 \mathrm{a}$ and $4 \mathrm{~b}$, respectively). Compared to unstretched hPDLSCs, TNF- $\alpha$-induced IL- 8 gene expression was not affected by CTS after $6 \mathrm{~h}$ (Fig. 3a). After $24 \mathrm{~h}$ incubation, CTS significantly decreased TNF- $\alpha$-induced
IL-8 expression using both, 6 and 12\% elongation (Fig. 3b). In contrast to gene expression, TNF- $\alpha$-induced IL- 8 protein level was significantly increased by CTS in a dose-dependent manner after $24 \mathrm{~h}$ (Fig. 4d). A similar tendency was also observed after $6 \mathrm{~h}$ but without any statistical significance (Fig. 4c).

\section{Effects of TNF- $a$ on VCAM-1 and ICAM-1 gene and protein expression}

Figure 5 shows the effect of TNF- $\alpha$ on VCAM- 1 and ICAM-1 expression in hPDLSCs. Exposure of hPDLSCs to TNF- $\alpha$ significantly enhanced gene and protein expression of VCAM-1 and ICAM-1 after both 6- and $24 \mathrm{~h}$. TNF$\alpha$-induced protein expression of ICAM-1 was significantly increased with time (Fig. 5d). In the absence of TNF- $\alpha$, hPDLSCs showed no VCAM-1 or ICAM-1 positive cell population.

\section{Effects of CTS on VCAM-1 gene expression and surface protein production in the absence and presence of TNF-a}

The effect of CTS on VCAM-1 expression in hPDLSCs under different experimental conditions is shown in Fig. 6. 
Fig. 4 Effects of CTS on IL-8 expression in the absence / presence of TNF- $\alpha$ in hPDLSCs. Primary hPDLSCs were subjected to either $6 \%$ or $12 \%$ cyclic stretching, in the absence or presence of $10 \mathrm{ng} /$ $\mathrm{ml}$ TNF- $\alpha$. IL- 8 gene expression levels were measured with RT-qPCR after 6 (a) or 24 (b) hours. TNF- $\alpha$-induced IL- 8 protein levels after 6 (c) and 24 (d) hours were quantified by ELISA. Y-axes show the effect of CTS on IL-8 expression as $\%$ of the values observed in unstretched cells with or without TNF- $\alpha$. For RT-qPCR $(\mathbf{a}, \mathbf{b}), \mathrm{n}$-fold gene expression was calculated first using the $2^{-\Delta \Delta \mathrm{Ct}}$ method and then the data were normalized to those observed in unstretched cells (dashed line). For ELISA (c, d), the values were calculated as $\%$ of the values measured in unstretched cells $(100 \%$, dashed line). The data are presented as the mean \pm standard deviation. * and $* *$ — significantly different compared to unstretched control with $p<0.05$ and $p<0.01$, respectively
A

IL-8, 6h

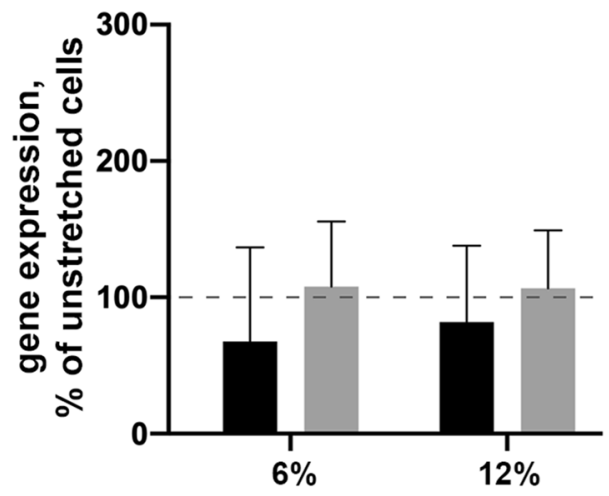

C

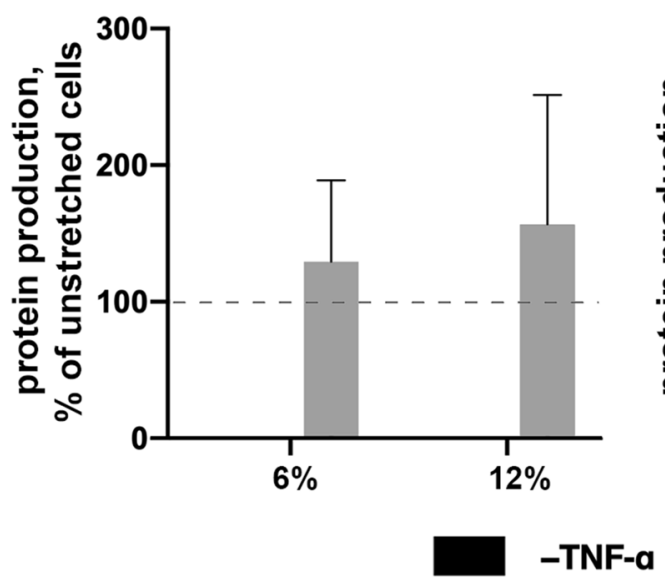

B

IL-8, 24h

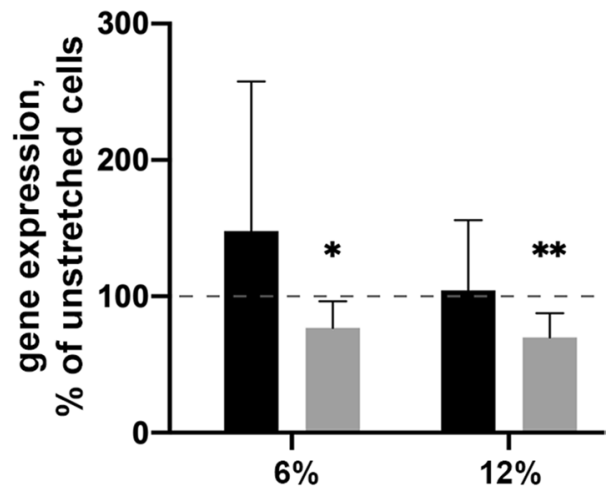

D

IL-8, 24h

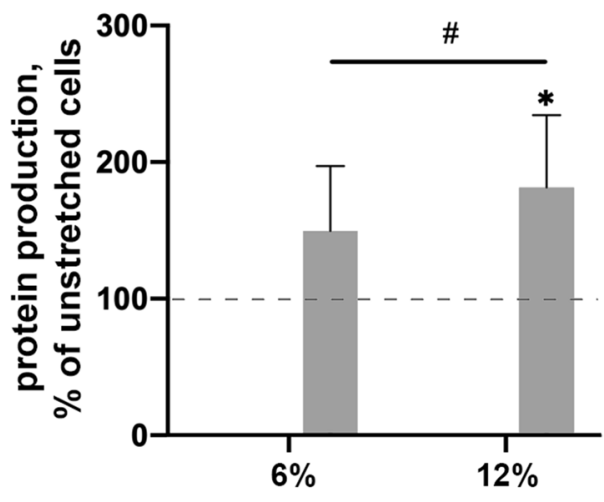

+TNF-a
Application of CTS on hPDLSCs had no significant effect on the VCAM-1 gene expression level in the absence of TNF- $\alpha$ after 6- or $24 \mathrm{~h}$ (Figs. 6a and b). Compared to unstretched hPDLSCs, TNF- $\alpha$-induced VCAM- 1 gene expression was significantly downregulated by $12 \%$ CTS after $6 \mathrm{~h}$ (Fig. 6a) and by CTS at both magnitudes after $24 \mathrm{~h}$ (Fig. 6b). Qualitatively similar results were observed for TNF- $\alpha$ - induced VCAM-1 protein expression. The percentage of VCAM-1 positive cells and the MFI of the positive cell population was decreased by $12 \%$ CTS after $6 \mathrm{~h}$ (Fig. 6c) and decreased by CTS at both magnitudes after $24 \mathrm{~h}$ (Fig. 6d).

\section{Effects of CTS on ICAM-1 gene and surface protein expression in the absence and presence of TNF-a}

Figure 7 shows the effect of CTS on basal and TNF- $\alpha$ induced ICAM-1 gene and protein expression in hPDLSCs. CTS applied on hPDLSCs did not influence the basal ICAM-1 gene expression level after both 6 - and $24 \mathrm{~h}$ (Figs. 7a and $7 \mathrm{~b}$, respectively). Compared to unstretched hPDLSCs, TNF- $\alpha$-induced ICAM-1 gene expression was not affected by CTS after $6 \mathrm{~h}$ (Fig. 7a) whereas it was downregulated by both $6 \%$ and $12 \%$ elongation after $24 \mathrm{~h}$ of incubation (Fig. 7b). The percentage of ICAM-1 positive cells induced by TNF- $\alpha$ was not affected by CTS (Figs. 7c and $7 \mathrm{~d}$ ). The MFI of the positive cell population was significantly decreased by $12 \%$ CTS after $6 \mathrm{~h}$ of incubation (Fig. 7c).

\section{Discussion}

During orthodontic treatment, periodontal ligament (PDL) transmits the mechanical forces into biological cues through responding to immediate strain induced by extracellular matrix deformation $[1,43]$. hPDLSCs play a central role in this process and participate in the adaptation of periodontal tissues to mechanical loading by mediating not only the selfrenewing of the ligament but also the remodeling of alveolar bone $[44,45]$. This process is initiated by an aseptic inflammatory response onsetting early several days after loading. Several in vitro studies demonstrated that CTS activates the production of numerous proinflammatory mediators [25, 46-49]. Moreover, application of CTS to human PDL cells 


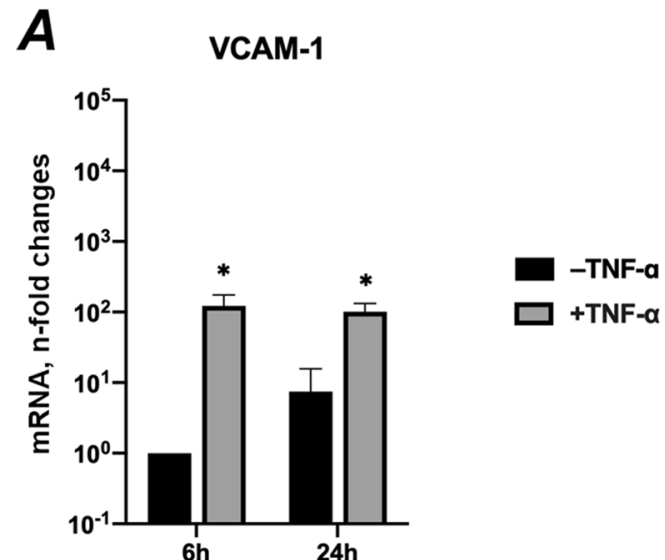

C

VCAM-1

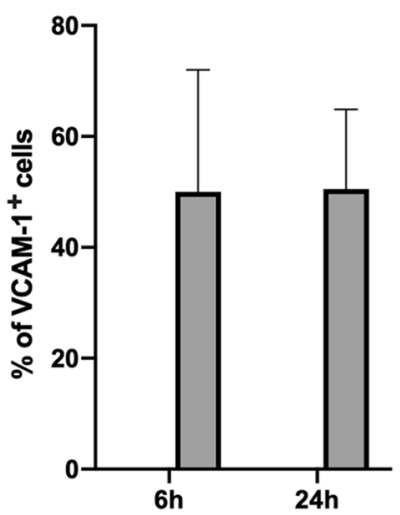

-TNF-a
$\square+$ TNF- $\alpha$
B

ICAM-1

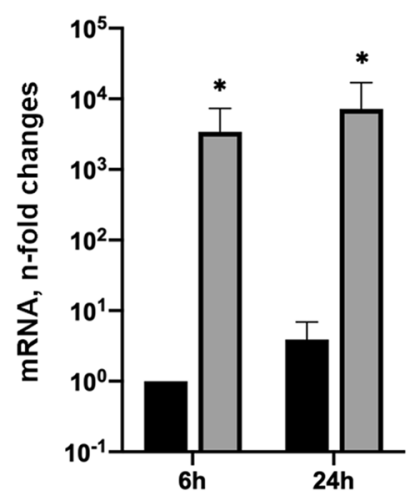

D

VCAM-1

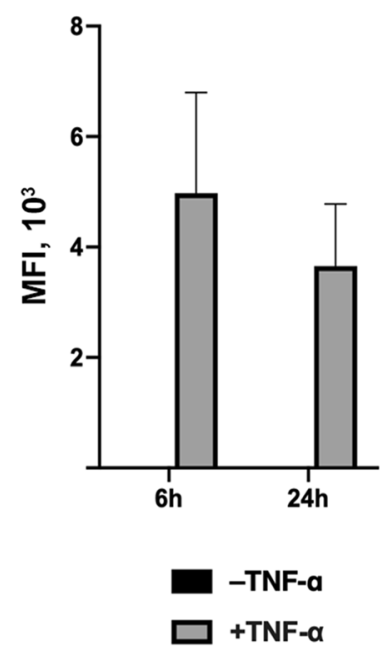

Fig. 5 Effects of TNF- $\alpha$ on gene and protein expression of VCAM-1 and ICAM-1 in unstretched hPDLSCs. Primary hPDLSCs were treated with $10 \mathrm{ng} / \mathrm{ml} \mathrm{TNF}-\alpha$ without mechanical stretching. The groups in the absence or presence of TNF- $\alpha$ are indicated as -TNF- $\alpha$ or $+\mathrm{TNF}-\alpha$, respectively. After $6-$ or $24 \mathrm{~h}$ of incubation, gene expression levels of VCAM-1 (a) and ICAM-1 (b) were measured using RT-qPCR. The Y-axes show the $\mathrm{n}$-fold changes in mRNA expression compared to untreated control after $6 \mathrm{~h}(\mathrm{n}$-fold expression $=1)$. The

in the presence of local periodontitis-related inflammation might aggravate the inflammatory processes $[9,29,30,50]$. Therefore, the initial inflammation induced by orthodontic forces maybe involved in the clinically co-destructive effect of the mechanical forces and periodontitis-induced tissue destruction [29]. However, some in vitro reports also showed that CTS might have either pro- or anti-inflammatory effects depending on the magnitude [28, 29, 31, 51, 52]. Therefore, the underlying mechanism of the co-destructive effect remains unclear.

In the present study, we investigated for the first time the effects of CTS on the hPDLSCs response to TNF- $\alpha$.
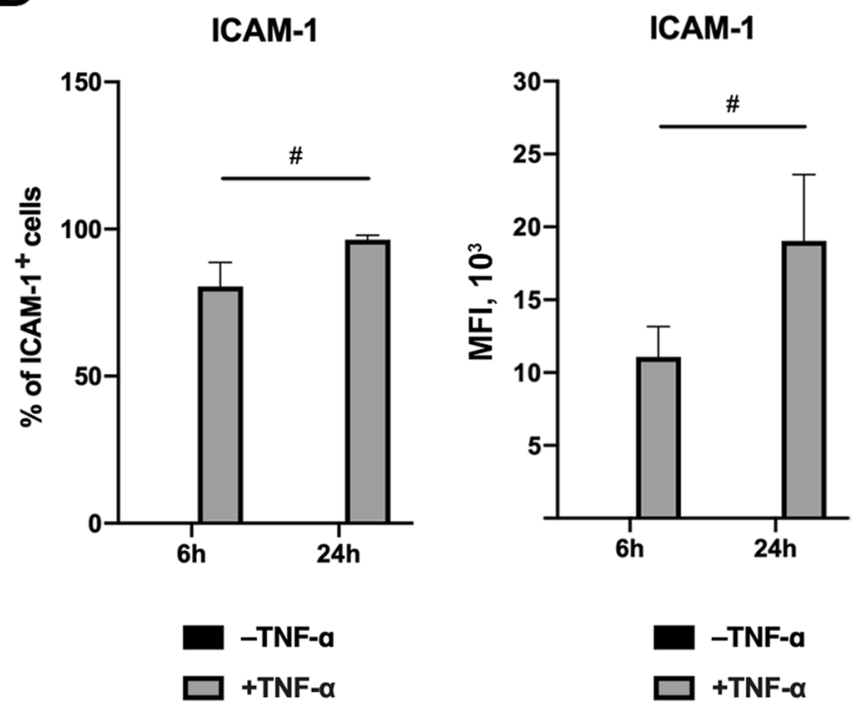

corresponding protein levels of VCAM-1 (c) and ICAM-1 (d) were quantified by flow cytometry. The Y-axes show the percentage of positive cells and the corresponding mean fluorescence intensity (MFI) of the positive cell population, respectively. No positively stained VCAM-1 and ICAM-1 cells were observed in the absence of TNF$\alpha$. The data are presented as the mean \pm standard deviation. $* p<0.05$ compared to corresponding control. ${ }^{\#} p<0.01$ compared between groups as indicated

CTS is commonly used in studies simulating orthodontic forces on the tension side in vitro $[9,30,32,39,40,50]$. The physiological relevance of the cyclic strain is rather disputable. Some researchers considered that translation of the orthodontic force from an individual tooth onto the single-cell involves the static force [4, 33, 53, 54] Application of superelastic nickel titanium springs displayed a typical force plateau [55]. Nevertheless, the cyclic force still plays a predominant role in the in vitro studies on orthodontic treatment $[30,32,39,40,56]$, when simulating the application of multibracket appliance together with occlusal forces [4, 57]. Moreover, the force range of CTS that is of 

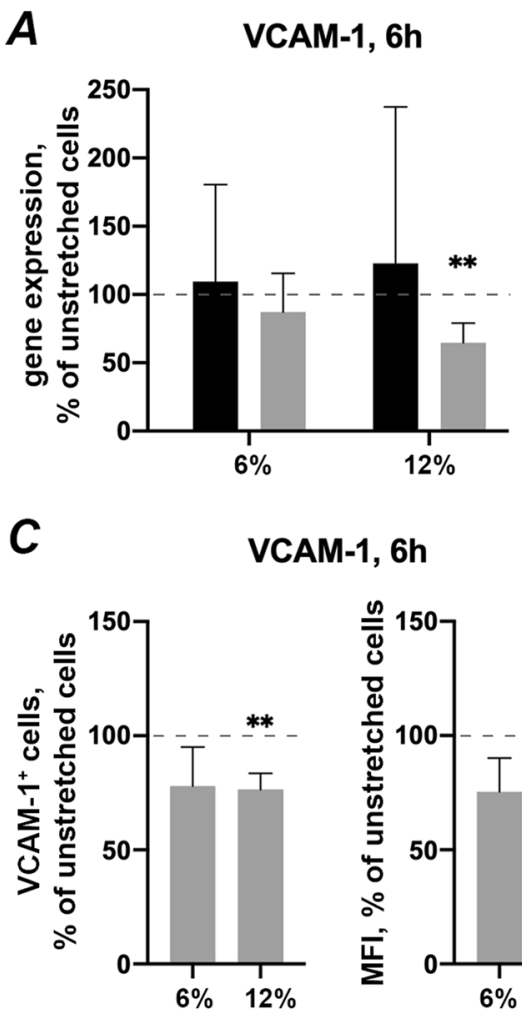

B

VCAM-1, 24h

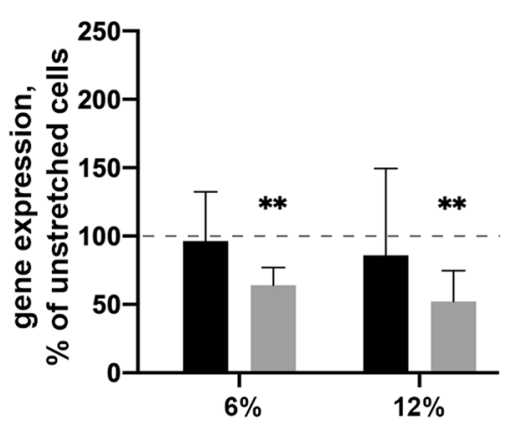

D

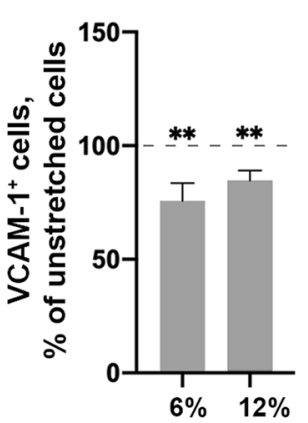

VCAM-1, 24h

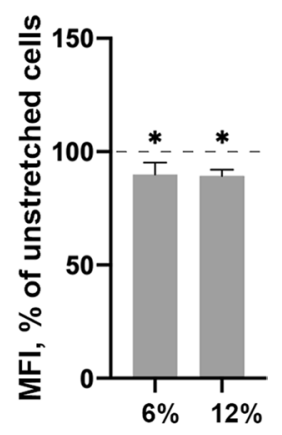

\section{-TNF-a}

+TNF-a

Fig. 6 Effects of CTS on VCAM-1 expression in the absence/presence of TNF- $\alpha$ in hPDLSCs. Primary hPDLSCs were subjected to either $6 \%$ or $12 \%$ cyclic stretching, in the absence or presence of $10 \mathrm{ng} / \mathrm{ml}$ TNF- $\alpha$. VCAM-1 gene expression levels were measured with RT-qPCR using the $2^{-\Delta \Delta \mathrm{Ct}}$ method after 6 (a) or 24 (b) hours. TNF- $\alpha$-induced VCAM- 1 protein levels after 6 (c) and 24 (d) hours were quantified by flow cytometry. Y-axes show the effect of CTS on VCAM-1 expression as \% of the values observed in unstretched cells with or without TNF- $\alpha$. For RT-qPCR (a, b), n-fold gene expression

therapeutic significance and within the physiological range $[9,28]$ is broader than that of static tensile force [53], resulting in easier manipulation and investigation of magnitudedependent effects.

A previous study showed that mechanical stress stimulates the expression of endogenous TNF- $\alpha$ among the other inflammatory mediators [49]. Theoretically, such production can enhance the inflammatory response in hPDLSCs, but such contribution is rather questionable for our study. This statement is based on the fact that the levels of TNF- $\alpha$ production by hPDLSCs are rather low. Even upon the stimulation with various bacteria the levels of TNF- $\alpha$ produced by hPDLSCs does not exceed $50 \mathrm{pg} / \mathrm{ml}$ [58], which is substantially lower than the concentration of exogenous TNF- $\alpha$ used in our experiments $(10 \mathrm{ng} / \mathrm{ml})$. Moreover, our own data show that in FBS-free media the levels of TNF- $\alpha$ in the conditioned media are below the detection limit of conventional ELISA, which is about a few pg/ml. was calculated first using the $2^{-\Delta \Delta \mathrm{Ct}}$ method and then the data were normalized to those observed in unstretched cells (dashed line). For protein expression (c, d), Y-axes show the percentage of positive cells and the mean fluorescence intensity (MFI) of the positive cell population, in $\%$ of the values measured in unstretched cells. The data are presented as the mean \pm standard deviation. $*$ and $* *$ - significantly different compared to unstretched control with $p<0.05$ and $p<0.01$, respectively

Of note, even though applying mechanical force directly on cells was widely conducted in in vitro studies, this simulation of orthodontic forces has some obvious limitations. Firstly, native paradental cells are surrounded by oriented PDL fibers when strained by tooth displacement during orthodontic tooth movement [23]. In tensioned PDL, cells are deformed within a specific three-dimensional structure, which cannot be reproduced by two-dimensional cell culture in vitro. Secondly, besides generating direct strain on matrix or cells, orthodontic forces disturb the blood flow and nerve endings, causing acute exudative inflammation and leading to a complicated biological environment [23, 59]. However, in vitro cells are cultured in an oversimplified environment, affected by the stretching alone during simulating orthodontal forces in vitro. Thirdly, due to the irreproducibility of the in vivo condition, the strain conditions of tooth displacements cannot be correlated well with the deformation condition of in vitro cell stretching; even 

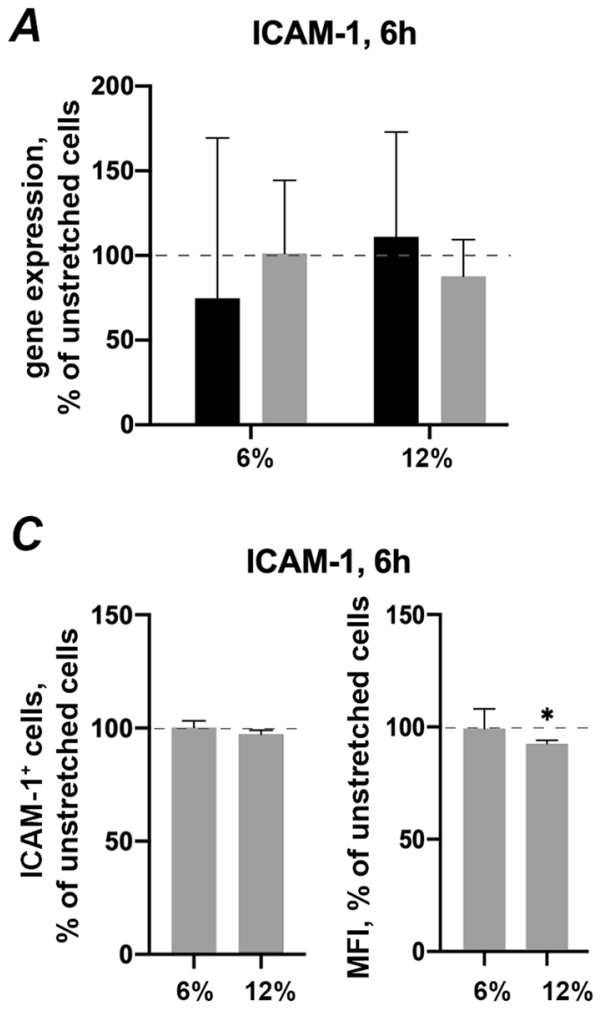

B

ICAM-1, 24h

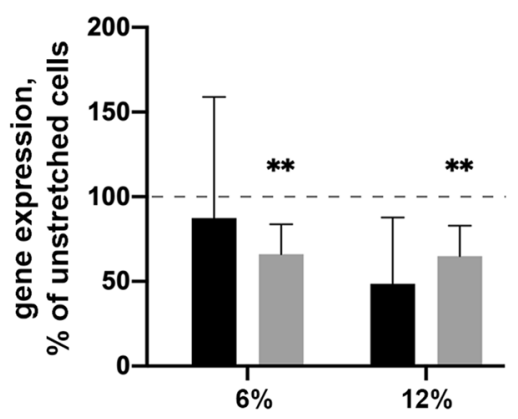

D

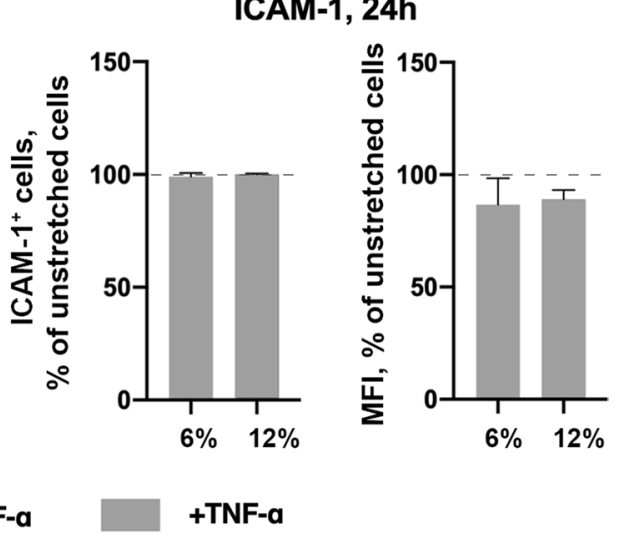

Fig. 7 Effects of CTS on ICAM-1 expression in the absence / presence of TNF- $\alpha$ in hPDLSCs. Primary hPDLSCs were subjected to either $6 \%$ or $12 \%$ cyclic stretching, in the absence or presence of $10 \mathrm{ng} / \mathrm{ml}$ TNF- $\alpha$. Unstretched hPDLSCs served as control. ICAM-1 gene expression levels were measured with RT-qPCR after 6 (a) or 24 (b) hours. TNF- $\alpha$-induced ICAM-1 protein levels after 6 (c) and 24 (d) hours were quantified by flow cytometry. Y-axes show the effect of CTS on ICAM-1 expression as \% of the values observed in unstretched cells with or without TNF- $\alpha$. For RT-qPCR (a, b),

though some researchers applied in vitro strain values based on the numerical data of PDL strains on a maxillary central incisor model [30, 56, 60-62].

In our study, we applied up to $12 \%$ CTS with the frequency of $0.1 \mathrm{~Hz}$ because it was the commonly used protocol for human PDL cells [37, 56, 62]. Magnitude is a critical parameter of CTS, which could bring on disparate effects on inflammatory responses, but the pattern of magnitudedependence was not reported consistently. CTS-modulated production of inflammatory cytokines, both under basal or inflammatory stimulation environment, was observed to increase with the force magnitude $[48,49,52]$ or remain no increase until a certain force magnitude level. [9, 28, 31]. Furthermore, the tolerance of PDL cells to CTS of different magnitude was shown to be decreased by periodontitis [9]. Therefore, the role of CTS magnitude was of interest for this study. 6 and $12 \%$ deformation were both identified to be within the physiological range based on their benefits $\mathrm{n}$-fold gene expression was calculated first using the $2^{-\Delta \Delta \mathrm{Ct}}$ method and then the data were normalized to those observed in unstretched cells (dashed line). For protein expression $(\mathbf{c}, \mathbf{d})$ the Y-axes show the percentage of positive cells and the mean fluorescence intensity (MFI) of the positive cell population, in \% of the values measured in unstretched cells. The data are presented as the mean \pm standard deviation. $*$ and $* *$ — significantly different compared to unstretched control with $p<0.05$ and $p<0.01$, respectively

to bone regeneration during orthodontic treatment [37]. For investigating inflammation regulation, $6 \%$ was commonly used within the "low force level" range, which normally exerted anti- or slightly pro-inflammatory effects in a force gradient $[28,31]$. Whereas $12 \%$ might be in a "critical range", which performed differently in different studies, generating apparent aggravation or no aggravation of inflammation $[28,49]$. The loading time periods of 6 - and $24 \mathrm{~h}$ were chosen to reflect initial stages of applied orthodontic forces [33].

The modulations of pro-inflammatory cytokines by mechanical stress have already been described in various studies. Briefly, mechanical stress with specific parameters can exert pro-inflammatory effects in human PDL cells, including up-regulation of IL-6 and IL-8. For example, the application of CTS with $10 \%$ elongation and a frequency of $1 \mathrm{~Hz}$ yielded an increased the level of IL-6 in primary human PDL cells within the first 2- or $6 \mathrm{~h}$ of strain [48]. 
Similar observations with an increased IL-6 have been made with the application of static tension [57], hydrostatic pressure (HP) [26], or vibration with $30 \mathrm{~Hz}$ [63]. Moreover, IL-8 expression was up-regulated under the application of $3 \sim 15 \%$ cyclic stretching with a frequency of $0.2 \mathrm{~Hz}$ after $24 \mathrm{~h}$ [49]. These studies indicate that human PDL cells are involved in the development of local aseptic inflammation after mechanical loading. However, our study demonstrated the CTS have no influence on the basal IL-6 and IL-8 expression. The contradictory data between our study and previous reports may be attributed to the differences in the applied strain, such as frequency and force types, various loading systems, and different culture plates.

Our data show that the expression of IL- 6 in TNF- $\alpha$ treated hPDLSCs was inhibited by CTS at both, 6 and $12 \%$ elongation. The effects of mechanical stress under an existing inflammatory microenvironment were frequently described as magnitude-dependent [9, 31, 64], emphasizing the force threshold of aggravating periodontitis. Although the parameters in these studies involved were different, generally, CTS with higher magnitudes caused a more pronounced aggravation of inflammation whereas lower magnitudes exerted more slightly pro-inflammatory, no pro-inflammatory, or even anti-inflammatory effects in some in vitro studies [28, 29, 31, 51]. For example, Liu J et al. [9] reported that CTS with less than $8 \%$ elongation induced the minimal inflammatory response in periodontitis derived hPDLSCs. CTS with 8\% elongation induced slighter enhancement of IL-6 than CTS with higher elongation. Similarly, CTS was reported to diminish IL-1 $\beta$ induced inflammatory response by some previous studies [28, 64]. Thus, low magnitude CTS seems to decrease IL- 6 production by hPDLSCs in the inflammatory environment.

Some contradictory data were obtained on the effect of cyclic mechanical strain on IL-8 expression in hPDLSCs in the presence of TNF- $\alpha$. On the one hand, TNF- $\alpha$-induced gene expression of IL- 8 was significantly decreased by the CTS. On the other hand, CTS enhanced TNF- $\alpha$-induced IL-8 protein production. This observation suggests that the regulation of IL- 8 gene expression by CTS may also occur at the post-transcriptional level. The mechanisms of such regulation in hPDLSCs are unclear to date but might involve some epigenetic factors and changes in mRNA expression. A study on human chondrocyte showed that the methylation of IL-8 promoter is decreased upon the stimulation with the pro-inflammatory cytokine IL-1 $\beta$ [65]. However, the existence of such an effect in hPDLSCs upon the stimulation with TNF- $\alpha$ should be proved. The mechanosensitive epigenetic factor was investigated in vascular endothelium. Epigenetic pathways respond to changes in blood flow and pressure in endothelial cells, with important consequences for regulating gene expression [66]. MicroRNAs (miRNAs) were reported mechanosensitive in endothelial cells, on which epigenetic modification regulates gene expression post-transcriptionally by targeting mRNA transcripts and regulating the mRNA lifetimes $[66,67]$. However, the specific effects of orthodontic forces on post-transcriptional modification in the response of hPDLSCs to inflammatory stimulation need to be studied in future studies.

Our data reported that CTS upregulated the protein level of IL- 8 induced by TNF- $\alpha$ after $24 \mathrm{~h}$. The increase depended on the force magnitude. These findings suggest that, under pathological conditions, IL- 8 is more sensitive to CTS than IL-6, implying the potential of IL-8 as a molecule marker for early monitoring orthodontic forces in periodontitis patients. IL-8 was reported to be elevated by mechanical forces both in human PDL cells in vitro and in animal OTM model especially in the tension area $[49,68]$, which is consistent with our findings. In short, the contribution of mechanical loading to periodontal inflammation cannot directly be summarized as pro- or anti-inflammatory effects. The underlying mechanism involves complex molecular signaling networks, needed further exploration.

VCAM-1 and ICAM-1 are adhesion molecules, which are usually expressed on endothelial cells and participate in the transendothelial migration of immune cells into connective tissue [69]. The expression of these molecules is upregulated by inflammatory cytokine like IL- $1 \beta$ and TNF- $\alpha$ [69]. Recent studies showed that VCAM-1 and ICAM-1 are expressed in the connective tissue cells, like gingival fibroblasts and human PDL cells, which may be related to the progression of periodontitis [70,71]. Our study is the first which demonstrates that CTS downregulated the TNF$\alpha$-induced VCAM- 1 and ICAM- 1 on hPDLSCs. The biomechanical responses of adhesion molecules were widely studied on endothelial cells due to the concern of heart valve diseases. The in vitro CTS were reported that it caused an up-regulation of VCAM-1 and ICAM-1 in endothelial cells [72, 73], but the results obtained from other studies were not consistent. Breen et al. reported that the upregulation of ICAM-1 in human umbilical vein endothelial cells (HUVEC) induced by shear stress was downregulated by the addition of CTS between 4 and 12\% [74]. The different effects may be attributed to the differences between application of physiological and pathological stretch [72].

\section{Conclusion}

In conclusion, this in vitro study demonstrated that application of CTS with $6 \%$ or $12 \%$ elongation decreased the TNF-a induced gene and protein expression of IL-6, VCAM-1 and ICAM-1. CTS decreased the TNF- $\alpha$ induced IL- 8 gene expression whereas it enhanced the protein production in a magnitude-dependent manner. Our study shows that mechanical force differentially regulates periodontitis-related 
inflammatory cytokines at the early stage of force application. The upregulation of IL- 8 and the downregulation of IL-6 indicate that the effects of orthodontic force on inflammation could not be simply defined by pro- or antiinflammation effects. Further investigations are needed to clarify the exact downstream effects of the cytokines on cell functions and cell behaviors. The inhibition of cell adhesion molecules suggests that mechanical sensitive mediators are involved in regulating the inflammatory processes, which provides an additional potential mechanism of the interaction between orthodontic forces and periodontitis.

Supplementary Information The online version contains supplementary material available at https://doi.org/10.1007/s00784-021-04039-8.

Acknowledgements The authors thank Phuong Quynh Nguyen for the excellent technical assistance. This study was funded by the Austrian Science Fund (FWF) (P 29440). Zhongqi Zhao was supported by China Scholarship Council (CSC) (No. 201806170075).

Author contribution Conceptualization: Zhongqi Zhao and Oleh Andrukhov; Methodology: Zhongqi Zhao, Christian Behm, Oleh Andrukhov; Formal analysis and investigation: Zhongqi Zhao, Marco Rausch and Zhiwei Tian; Writing — original draft preparation: Zhongqi Zhao; Writing_-review and editing: Oleh Andrukhov, Christian Behm, Marco Rausch, Zhiwei Tian and Xiaohui Rausch-Fan; Funding acquisition: Oleh Andrukhov; Resources: Oleh Andrukhov and Xiaohui Rausch-Fan; Supervision: Oleh Andrukhov and Xiaohui Rausch-Fan. All authors read and approved the final manuscript.

Funding Open access funding provided by Austrian Science Fund (FWF). Open access funding provided by Medical University of Vienna.

\section{Declarations}

Ethics approval and consent to participate All procedures performed in studies involving human participants were in accordance with the ethical standards of the institutional and/or national research committee and with the 1964 Helsinki Declaration and its later amendments or comparable ethical standards. The study was approved by the Ethics Committee of the Medical University of Vienna (ethical approval number: 1079/2019, extended in 2020). Informed consent was obtained from all individual participants included in the study.

Conflict of interest The authors declare no competing interests.

Open Access This article is licensed under a Creative Commons Attribution 4.0 International License, which permits use, sharing, adaptation, distribution and reproduction in any medium or format, as long as you give appropriate credit to the original author(s) and the source, provide a link to the Creative Commons licence, and indicate if changes were made. The images or other third party material in this article are included in the article's Creative Commons licence, unless indicated otherwise in a credit line to the material. If material is not included in the article's Creative Commons licence and your intended use is not permitted by statutory regulation or exceeds the permitted use, you will need to obtain permission directly from the copyright holder. To view a copy of this licence, visit http://creativecommons.org/licenses/by/4.0/.

\section{References}

1. Proffit WR (2018) Contemporary orthodontics. 6th edition. edn. Elsevier, Philadelphia, IL

2. McCulloch CA, Lekic P, McKee MD (2000) Role of physical forces in regulating the form and function of the periodontal ligament. Periodontol 24:56-72. https://doi.org/10.1034/j.1600-0757. 2000.2240104.x

3. Jin Y, Ding L, Ding Z, Fu Y, Song Y, Jing Y, Li Q, Zhang J, Ni Y, $\mathrm{Hu} \mathrm{Q}$ (2020) Tensile force-induced PDGF-BB/PDGFRbeta signals in periodontal ligament fibroblasts activate JAK2/STAT3 for orthodontic tooth movement. Sci Rep 10(1):11269. https://doi. org/10.1038/s41598-020-68068-1

4. Behm C, Nemec M, Blufstein A, Schubert M, Rausch-Fan X, Andrukhov O, Jonke E (2021) Interleukin-1beta induced matrix metalloproteinase expression in human periodontal ligamentderived mesenchymal stromal cells under in vitro simulated static orthodontic forces. Int J Mol Sci 22:3. https://doi.org/10. 3390/ijms22031027

5. Ivanovski S, Gronthos S, Shi S, Bartold PM (2006) Stem cells in the periodontal ligament. Oral Dis 12(4):358-363. https:// doi.org/10.1111/j.1601-0825.2006.01253.x

6. Nagatomo K, Komaki M, Sekiya I, Sakaguchi Y, Noguchi K, Oda S, Muneta T, Ishikawa I (2006) Stem cell properties of human periodontal ligament cells. J Periodontal Res 41(4):303310. https://doi.org/10.1111/j.1600-0765.2006.00870.x

7. Andrukhov O, Behm C, Blufstein A, Rausch-Fan X (2019) Immunomodulatory properties of dental tissue-derived mesenchymal stem cells: implication in disease and tissue regeneration. World J Stem Cells 11(9):604-617. https://doi.org/10. 4252/wjsc.v11.i9.604

8. Huang H, Yang R, Zhou YH (2018) Mechanobiology of periodontal ligament stem cells in orthodontic tooth movement. Stem Cells Int 2018:6531216. https://doi.org/10.1155/2018/6531216

9. Liu J, Li Q, Liu S, Gao J, Qin W, Song Y, Jin Z (2017) Periodontal ligament stem cells in the periodontitis microenvironment are sensitive to static mechanical strain. Stem Cells Int 2017:1380851. https://doi.org/10.1155/2017/1380851

10. Gyawali R, Bhattarai B (2017) Orthodontic management in aggressive periodontitis. Int Sch Res Notices 2017:8098154. https://doi.org/10.1155/2017/8098154

11. Boas Nogueira AV, Chaves de Souza JA, Kim YJ, Damiao de Sousa-Neto M, Chan Cirelli C, Cirelli JA (2013) Orthodontic force increases interleukin-1beta and tumor necrosis factoralpha expression and alveolar bone loss in periodontitis. J Periodontol 84(9):1319-1326. https://doi.org/10.1902/jop.2012. 120510

12. Wennstrom JL, Stokland BL, Nyman S, Thilander B (1993) Periodontal tissue response to orthodontic movement of teeth with infrabony pockets. Am J Orthod Dentofacial Orthop 103(4):313-319. https://doi.org/10.1016/0889-5406(93) 70011-C

13. Yang JH, Li ZC, Kong WD, Zhang W, Jia YP, Zhang YL, Liu LB, Han XP (2013) Effect of orthodontic force on inflammatory periodontal tissue remodeling and expression of IL-6 and IL-8 in rats. Asian Pac J Trop Med 6(10):757-761. https://doi.org/10. 1016/S1995-7645(13)60133-9

14. Kirschneck C, Fanghanel J, Wahlmann U, Wolf M, Roldan JC, Proff P (2017) Interactive effects of periodontitis and orthodontic tooth movement on dental root resorption, tooth movement velocity and alveolar bone loss in a rat model. Ann Anat 210:32-43. https://doi.org/10.1016/j.aanat.2016.10.004

15. Yucel-Lindberg $\mathrm{T}$, Bage $\mathrm{T}$ (2013) Inflammatory mediators in the pathogenesis of periodontitis. Expert Rev Mol Med 15:e7. https:// doi.org/10.1017/erm.2013.8 
16. Liu X, Tan GR, Yu M, Cai X, Zhou Y, Ding H, Xie H, Qu F, Zhang R, Lam CU, Cui P, Fu B (2016) The effect of tumour necrosis factor-alpha on periodontal ligament stem cell differentiation and the related signaling pathways. Curr Stem Cell Res Ther 11(7):593-602. https://doi.org/10.2174/1574888x1166616 0429122858

17. Baud V, Karin M (2001) Signal transduction by tumor necrosis factor and its relatives. Trends Cell Biol 11(9):372-377. https:// doi.org/10.1016/s0962-8924(01)02064-5

18 Choi HJ, Kim NE, Kim BM, Seo M, Heo JH (2018) TNF-alphainduced YAP/TAZ activity mediates leukocyte-endothelial adhesion by regulating VCAM1 expression in endothelial cells. Int J Mol Sci 19:11. https://doi.org/10.3390/ijms19113428

19. Kurihara N, Bertolini D, Suda T, Akiyama Y, Roodman GD (1990) Il-6 Stimulates osteoclast-like multinucleated cell-formation in long-term human marrow cultures by inducing Il-1 release. J Immunol 144(11):4226-4230

20. Irwin CR, Myrillas TT (1998) The role of IL-6 in the pathogenesis of periodontal disease. Oral Dis 4(1):43-47. https://doi.org/10. 1111/j.1601-0825.1998.tb00255.x

21. Baggiolini M, Walz A, Kunkel SL (1989) Neutrophil-activating peptide-1/interleukin 8 , a novel cytokine that activates neutrophils. J Clin Invest 84(4):1045-1049. https://doi.org/10.1172/ JCI114265

22. Ren G, Zhao X, Zhang L, Zhang J, L'Huillier A, Ling W, Roberts AI, Le AD, Shi S, Shao C, Shi Y (2010) Inflammatory cytokineinduced intercellular adhesion molecule- 1 and vascular cell adhesion molecule-1 in mesenchymal stem cells are critical for immunosuppression. J Immunol 184(5):2321-2328. https://doi.org/10. 4049/jimmunol.0902023

23. Li Y, Jacox LA, Little SH, Ko CC (2018) Orthodontic tooth movement: the biology and clinical implications. Kaohsiung J Med Sci 34(4):207-214. https://doi.org/10.1016/j.kjms.2018.01.007

24. Yamaguchi M, Kasai K (2005) Inflammation in periodontal tissues in response to mechanical forces. Arch Immunol Ther Exp (Warsz) 53(5):388-398

25. Shimizu N, Yamaguchi M, Goseki T, Ozawa Y, Saito K, Takiguchi $\mathrm{H}$, Iwasawa T, Abiko Y (1994) Cyclic-tension force stimulates interleukin-1-beta production by human periodontal-ligament cells. J Periodontal Res 29(5):328-333. https://doi.org/10.1111/j. 1600-0765.1994.tb01230.x

26. Yamamoto T, Kita M, Kimura I, Oseko F, Terauchi R, Takahashi K, Kubo T, Kanamura N (2006) Mechanical stress induces expression of cytokines in human periodontal ligament cells. Oral Dis 12(2):171-175. https://doi.org/10.1111/j.1601-0825.2005.01179.x

27. Musacchio E, Valvason C, Botsios C, Ostuni F, Furlan A, Ramonda R, Modesti V, Sartori L, Punzi L (2009) The tumor necrosis factor- $\{$ alpha $\}$-blocking agent infliximab inhibits interleukin 1 beta (IL-1beta) and IL-6 gene expression in human osteoblastic cells. J Rheumatol 36(8):1575-1579. https://doi.org/10. 3899/jrheum.081321

28. Agarwal S, Long P, Seyedain A, Piesco N, Shree A, Gassner R (2003) A central role for the nuclear factor-kappaB pathway in anti-inflammatory and proinflammatory actions of mechanical strain. FASEB J 17(8):899-901. https://doi.org/10.1096/fj.020901fje

29. Nogueira AV, Nokhbehsaim M, Eick S, Bourauel C, Jager A, Jepsen S, Rossa C Jr, Deschner J, Cirelli JA (2014) Biomechanical loading modulates proinflammatory and bone resorptive mediators in bacterial-stimulated PDL cells. Mediators Inflamm 2014:425421. https://doi.org/10.1155/2014/425421

30. Sun C, Liu F, Cen S, Chen L, Wang Y, Sun H, Deng H, Hu R (2017) Tensile strength suppresses the osteogenesis of periodontal ligament cells in inflammatory microenvironments. Mol Med Rep 16(1):666-672. https://doi.org/10.3892/mmr.2017.6644
31. Long P, Hu J, Piesco N, Buckley M, Agarwal S (2001) Low magnitude of tensile strain inhibits IL-1 beta-dependent induction of pro-inflammatory cytokines and induces synthesis of IL-10 in human periodontal ligament cells in vitro. J Dent Res 80(5):14161420. https://doi.org/10.1177/00220345010800050601

32. Nokhbehsaim M, Deschner B, Winter J, Reimann S, Bourauel C, Jepsen S, Jager A, Deschner J (2010) Contribution of orthodontic load to inflammation-mediated periodontal destruction. J Orofac Orthop 71(6):390-402. https://doi.org/10.1007/ s00056-010-1031-7

33. Huelter-Hassler D, Tomakidi P, Steinberg T, Jung BA (2017) Orthodontic strain affects the Hippo-pathway effector YAP concomitant with proliferation in human periodontal ligament fibroblasts. Eur J Orthod 39(3):251-257. https://doi.org/10.1093/ejo/ cjx012

34. Krishnan V, Davidovitch Z (2006) Cellular, molecular, and tissue-level reactions to orthodontic force. Am J Orthod Dentofacial Orthop 129(4):469-e461 432. https://doi.org/10.1016/j.ajodo. 2005.10.007

35. Dominici M, Le Blanc K, Mueller I, Slaper-Cortenbach I, Marini F, Krause D, Deans R, Keating A, Prockop D, Horwitz E (2006) Minimal criteria for defining multipotent mesenchymal stromal cells. The International Society for Cellular Therapy position statement. Cytotherapy 8(4):315-317. https://doi.org/10.1080/ 14653240600855905

36. Viswanathan S, Shi Y, Galipeau J, Krampera M, Leblanc K, Martin I, Nolta J, Phinney DG, Sensebe L (2019) Mesenchymal stem versus stromal cells: International Society for Cell \& Gene Therapy (ISCT(R)) Mesenchymal Stromal Cell committee position statement on nomenclature. Cytotherapy 21(10):1019-1024. https://doi.org/10.1016/j.jcyt.2019.08.002

37. Shen T, Qiu L, Chang H, Yang Y, Jian C, Xiong J, Zhou J, Dong $S$ (2014) Cyclic tension promotes osteogenic differentiation in human periodontal ligament stem cells. Int J Clin Exp Pathol 7(11):7872-7880

38. Ozaki S, Kaneko S, Podyma-Inoue KA, Yanagishita M, Soma K (2005) Modulation of extracellular matrix synthesis and alkaline phosphatase activity of periodontal ligament cells by mechanical stress. J Periodontal Res 40(2):110-117. https://doi.org/10.1111/j. 1600-0765.2004.00782.x

39. Wei FL, Wang JH, Ding G, Yang SY, Li Y, Hu YJ, Wang SL (2014) Mechanical force-induced specific microRNA expression in human periodontal ligament stem cells. Cells Tissues Organs 199(5-6):353-363. https://doi.org/10.1159/000369613

40. Wu J, Song M, Li T, Zhu Z, Pan J (2015) The Rho-mDia1 signaling pathway is required for cyclic strain-induced cytoskeletal rearrangement of human periodontal ligament cells. Exp Cell Res 337(1):28-36. https://doi.org/10.1016/j.yexcr.2015.07.016

41. Blufstein A, Behm C, Nguyen PQ, Rausch-Fan X, Andrukhov O (2018) Human periodontal ligament cells exhibit no endotoxin tolerance upon stimulation with Porphyromonas gingivalis lipopolysaccharide. J Periodontal Res 53(4):589-597. https://doi.org/10. $1111 /$ jre. 12549

42. Andrukhov O, Steiner I, Liu S, Bantleon HP, Moritz A, RauschFan X (2015) Different effects of Porphyromonas gingivalis lipopolysaccharide and TLR2 agonist Pam3CSK4 on the adhesion molecules expression in endothelial cells. Odontology 103(1):19 26. https://doi.org/10.1007/s10266-013-0146-x

43. Isola G, Matarese G, Cordasco G, Perillo L, Ramaglia L (2016) Mechanobiology of the tooth movement during the orthodontic treatment: a literature review. Minerva Stomatol 65(5):299-327

44. Kim T, Handa A, Iida J, Yoshida S (2007) RANKL expression in rat periodontal ligament subjected to a continuous orthodontic force. Arch Oral Biol 52(3):244-250. https://doi.org/10.1016/j. archoralbio.2006.10.003 
45. Lekic P, McCulloch CAG (1996) Periodontal ligament cell populations: The central role of fibroblasts in creating a unique tissue. Anat Rec 245(2):327-341

46. Shimizu N, Ozawa Y, Yamaguchi M, Goseki T, Ohzeki K, Abiko Y (1998) Induction of COX-2 expression by mechanical tension force in human periodontal ligament cells. J Periodontol 69(6):670-677. https://doi.org/10.1902/jop.1998.69.6.670

47. Suzuki R, Nemoto E, Shimauchi H (2014) Cyclic tensile force up-regulates BMP-2 expression through MAP kinase and COX-2/ PGE2 signaling pathways in human periodontal ligament cells. Exp Cell Res 323(1):232-241. https://doi.org/10.1016/j.yexcr. 2014.02.013

48. Tantilertanant Y, Niyompanich J, Everts V, Supaphol P, Pavasant P, Sanchavanakit N (2019) Cyclic tensile force-upregulated IL6 increases MMP3 expression by human periodontal ligament cells. Arch Oral Biol 107:104495. https://doi.org/10.1016/j.archoralbio. 2019.104495

49. Lee SI, Park KH, Kim SJ, Kang YG, Lee YM, Kim EC (2012) Mechanical stress-activated immune response genes via Sirtuin 1 expression in human periodontal ligament cells. Clin Exp Immunol 168(1):113-124. https://doi.org/10.1111/j.1365-2249.2011. 04549.x

50. Cho JH, Lee SK, Lee JW, Kim EC (2010) The role of heme oxygenase-1 in mechanical stress- and lipopolysaccharide-induced osteogenic differentiation in human periodontal ligament cells. Angle Orthod 80(4):552-559. https://doi.org/10.2319/091509-520.1

51. Nokhbehsaim M, Deschner B, Winter J, Bourauel C, Jager A, Jepsen S, Deschner J (2012) Anti-inflammatory effects of EMD in the presence of biomechanical loading and interleukin-1beta in vitro. Clin Oral Investig 16(1):275-283. https://doi.org/10. 1007/s00784-010-0505-8

52. Wang ZY, Maruyama K, Sakisaka Y, Suzuki S, Tada H, Suto M, Saito M, Yamada S, Nemoto E (2019) Cyclic stretch force induces periodontal ligament cells to secrete exosomes that suppress IL-1 beta production through the inhibition of the NF-kappa B signaling pathway in macrophages. Front Immunol 10:1310. https://doi. org/10.3389/fimmu.2019.01310

53. Ziegler N, Alonso A, Steinberg T, Woodnutt D, Kohl A, Mussig E, Schulz S, Tomakidi P (2010) Mechano-transduction in periodontal ligament cells identifies activated states of MAP-kinases p42/44 and p38-stress kinase as a mechanism for MMP-13 expression. Bmc Cell Biol 11:10. https://doi.org/10.1186/1471-2121-11-10

54. Jacobs C, Walter C, Ziebart T, Dirks I, Schramm S, Grimm S, Krieger E, Wehrbein H (2015) Mechanical loading influences the effects of bisphosphonates on human periodontal ligament fibroblasts. Clin Oral Investig 19(3):699-708. https://doi.org/10.1007/ s00784-014-1284-4

55. Brauchli LM, Senn C, Ball J, Wichelhaus A (2011) Force levels of 23 nickel-titanium open-coil springs in compression testing. Am J Orthod Dentofacial Orthop 139(5):601-605. https://doi.org/10. 1016/j.ajodo.2009.06.033

56. Wescott DC, Pinkerton MN, Gaffey BJ, Beggs KT, Milne TJ, Meikle MC (2007) Osteogenic gene expression by human periodontal ligament cells under cyclic tension. J Dent Res 86(12):1212-1216. https://doi.org/10.1177/154405910708601214

57. Jacobs C, Walter C, Ziebart T, Grimm S, Meila D, Krieger E, Wehrbein H (2014) Induction of IL-6 and MMP-8 in human periodontal fibroblasts by static tensile strain. Clin Oral Investig 18(3):901-908. https://doi.org/10.1007/s00784-013-1032-1

58. Yamamoto T, Kita M, Oseko F, Nakamura T, Imanishi J, Kanamura N (2006) Cytokine production in human periodontal ligament cells stimulated with Porphyromonas gingivalis. J Periodontal Res 41(6):554-559. https://doi.org/10.1111/j.1600-0765.2006. 00905.x
59. Wise GE, King GJ (2008) Mechanisms of tooth eruption and orthodontic tooth movement. J Dent Res 87(5):414-434. https:// doi.org/10.1177/154405910808700509

60. Natali AN, Pavan PG, Scarpa C (2004) Numerical analysis of tooth mobility: formulation of a non-linear constitutive law for the periodontal ligament. Dent Mater 20(7):623-629. https://doi. org/10.1016/j.dental.2003.08.003

61. Saminathan A, Vinoth KJ, Wescott DC, Pinkerton MN, Milne TJ, Cao T, Meikle MC (2012) The effect of cyclic mechanical strain on the expression of adhesion-related genes by periodontal ligament cells in two-dimensional culture. J Periodontal Res 47(2):212-221. https://doi.org/10.1111/j.1600-0765.2011.01423.x

62. Chen Y, Mohammed A, Oubaidin M, Evans CA, Zhou X, Luan X, Diekwisch TG, Atsawasuwan P (2015) Cyclic stretch and compression forces alter microRNA-29 expression of human periodontal ligament cells. Gene 566(1):13-17. https://doi.org/ 10.1016/j.gene.2015.03.055

63. Phusuntornsakul P, Jitpukdeebodintra S, Pavasant $P$, Leethanakul C (2020) Vibration activates the actin/NF-kappa B axis and upregulates IL-6 and IL-8 expression in human periodontal ligament cells. Cell Biol Int 44(2):661-670. https://doi.org/10.1002/cbin. 11267

64. Long P, Liu F, Piesco NP, Kapur R, Agarwal S (2002) Signaling by mechanical strain involves transcriptional regulation of proinflammatory genes in human periodontal ligament cells in vitro. Bone 30(4):547-552. https://doi.org/10.1016/s8756-3282(02) 00673-7

65. Takahashi A, de Andres MC, Hashimoto K, Itoi E, Oreffo RO (2015) Epigenetic regulation of interleukin-8, an inflammatory chemokine, in osteoarthritis. Osteoarthritis Cartilage 23(11):1946-1954. https://doi.org/10.1016/j.joca.2015.02.168

66. Davies PF, Manduchi E, Jimenez JM, Jiang YZ (2017) Biofluids, cell mechanics and epigenetics: flow-induced epigenetic mechanisms of endothelial gene expression. J Biomech 50:3-10. https:// doi.org/10.1016/j.jbiomech.2016.11.017

67. Kumar S, Kim CW, Simmons RD, Jo H (2014) Role of flowsensitive microRNAs in endothelial dysfunction and atherosclerosis: mechanosensitive athero-miRs. Arterioscler Thromb Vasc Biol 34(10):2206-2216. https://doi.org/10.1161/ATVBAHA.114. 303425

68. Tuncer BB, Ozmeric N, Tuncer C, Teoman I, Cakilci B, Yucel A, Alpar R, Balos K (2005) Levels of interleukin-8 during tooth movement. Angle Orthod 75(4):631-636. https://doi.org/10.1043/ 0003-3219(2005)75[631:LOIDTM]2.0.CO;2

69. Pober JS, Cotran RS (1990) Cytokines and endothelial cell biology. Physiol Rev 70(2):427-451. https://doi.org/10.1152/physrev. 1990.70.2.427

70. Hosokawa Y, Hosokawa I, Ozaki K, Nakae H, Matsuo T (2006) Cytokines differentially regulate ICAM-1 and VCAM-1 expression on human gingival fibroblasts. Clin Exp Immunol 144(3):494-502. https://doi.org/10.1111/j.1365-2249.2006. 03064.x

71. Liu JR, Wang YX, Ouyang XY (2014) Beyond toll-like receptors: Porphyromonas gingivalis induces IL-6, IL-8, and VCAM-1 expression through NOD-mediated NF-kappa B and ERK signaling pathways in periodontal fibroblasts. Inflammation 37(2):522533. https://doi.org/10.1007/s10753-013-9766-0

72. Meza D, Musmacker B, Steadman E, Stransky T, Rubenstein DA, Yin W (2019) Endothelial cell biomechanical responses are dependent on both fluid shear stress and tensile strain. Cell Mol Bioeng 12(4):311-325. https://doi.org/10.1007/ s12195-019-00585-0

73. Metzler SA, Pregonero CA, Butcher JT, Burgess SC, Warnock JN (2008) Cyclic strain regulates pro-inflammatory protein expression in porcine aortic valve endothelial cells. J Heart Valve Dis 17(5):571-578 
74. Breen LT, McHugh PE, Murphy BP (2009) Multi-axial mechanical stimulation of HUVECs demonstrates that combined loading is not equivalent to the superposition of individual wall shear stress and tensile hoop stress components. J Biomech Eng 131:8. https://doi.org/10.1115/1.3127248
Publisher's note Springer Nature remains neutral with regard to jurisdictional claims in published maps and institutional affiliations. 